\title{
CORRESPONDENCE
}

\section{Environment Conference}

SIR,- I should like you to know how much I appreciated the coverage of the Canberra meeting of SCOPE on September $1-3^{1}$. I must point out, though, that your correspondent entirely misunderstood the main thrust of my remarks on the question of the organization of environmental activities within the UN system. Far from advocating the creation of a "new agency", I specifically pointed out that environmental affairs do not lend themselves to the creation of another new specialized agency because they involve the interaction of a number of cause and effect relationships which transcend the traditional boundaries of sectors and institutions. I emphasized that we are still at too early a stage in our consideration of this important question to know what decisions governments will take concerning it at Stockholm. In outlining my own views as to the present state of thinking by governments, I made two points: (1) that some form of continuing machinery will be needed at the international level after the Stockholm Conference to follow up the decisions taken at Stockholm, and (2) that what is required principally is a better means of coordinating and providing a central forum and a concerted sense of direction to the environmental activities of the existing international organizations, rather than a new specialized agency.

I have set out here a list of the criteria which should, in my view, as I said at Canberra, be applied in determining the kind of international organizational arrangements that may be made following the Stockholm Conference. As these have been accepted in principle by the Preparatory Committee of twenty-seven governments set up by the UN General Assembly, and I believe are fully compatible with the views of the UN agencies concerned, they represent a reasonable indication of present thinking on this important subject. (a) Any organizational arrangements should be based first on agreement about what needs to be done. Until this is reached, no firm decision can be made on the ways and means to be adopted. (b) All functions that can best be performed by existing organizations should be assigned to those organizations, both international and national, most capable of carrying them out effectively. No unnecessary new machinery should be created. (c) It is more logical to consider a network of national, international, functional and sectoral organizations with appropriate linkages and "switchboard" mechanisms, whereby international organizations supplement and complement national organizations, than to think in terms of a global "super agency". (d) Any action envisaged should allow for the preliminary state of knowledge and understanding of environmental problems, and should be flexible and evolutionary. (e) Governments will want to attach highest priority to the need for coordination and rationalization of the activities and programmes of the various international organizations active in the environmental field. This is essential in order to avoid overlap and duplication and to assure most effective use of scarce resources of money and manpower. (f) Any policy centre that is expected to influence and coordinate the activities of other agencies should not itself have operational functions which in any way compete with the organizations over which it expects to exercise such influence. (g) In the establishment of any additional or new machinery it is essential to provide strong capability at the regional level. (h) The United Nations should be the principal centre for international environmental cooperation. (i) The organization of environmental activities within the United Nations should be so designed as to strengthen and reinforce the entire United Nations system.

While there can be and no doubt will be differences of view both in the UN family and amongst governments concerning the specific decisions which must be taken at Stockholm in applying these criteria, the degree of consensus that has already been achieved is a hopeful sign that these differences will be resolved successfully. The basic purpose of the preparatory process preceding Stockholm is precisely to enable all the relevant views to be fully discussed and reflected in the decisions governments will be asked to take at Stockholm.

Yours faithfully,

Maurice F. Strong

Secretary-General of the Conference

United Nations Conference

on the Human Environment, Stockholm

'Nature, 233, 81 (1971).

\section{Responsibility and the US National Academy}

SIR,-In the November 5 issue of Nature $(234,7$; 1971) there was a fairly extensive report of the reaction of the National Academy of Sciences to my resignation from that august body. In amplification of that report $I$ would like to make a minor and a major point. The minor point is that I am in fact no longer a member of the National Academy, having ceased to be a member on the day of my resignation. Whether the Academy chooses or does not choose to accept my resignation is of no consequence. As I wrote recently to the President, "Membership in a voluntary association demands consent. I have withdrawn my consent".

The major issue concerns the meaning of responsibility. Apparently reports of the NAS-NRC in the future will carry a disclaimer of responsibility by all members of the Academy except for those who may have actually served on the working committee. It is suggested by your correspondent that this goes some significant way toward meeting my objections to the Academy's secret research. No one who is not either politically naive or Machiavellian can subscribe to such a view. "Responsibility" means both literally and in practice that one is in a 
position to be "called to account". Thus, responsibility inheres in a social relation and is defined by those who will do the calling, not by those who are called. It would be very convenient, of course, if each of us could define for himself when he was or was not responsible. Perhaps I could put a large sign on my car saying "This car is none too reliable and I will not be responsible for anyone killed by it". Mr Eichman said he only made up train schedules and was not responsible for what happened to people at the other end of the line. But Mr Eichman's victims and their families called him to account. It was they who defined the responsibility. The fact of responsibility cannot be waved away by wishful thinking. The facts are: (1) The National Research Council is the "operating arm of the National Academy". (2) The President of the Academy heads the National Research Council. (3) Officers of the National Academy have the power to determine policy of the National Research Council. (4) According to a letter from the President of the Academy, "The prestige of the National Academy of Sciences is used to recruit working Committees of the National Research Council". (5) The prestige of the National Academy stands behind every report and, indeed, every report has been reviewed by a special committee of the Academy.

Thus the Academy is responsible and no legal fiction of its own devising will change that fact. The best the members of the Academy can hope for is that accounts will not be called in their lifetime, or, if events move more swiftly, that the National Academy will be seen, in retrospect, as unimportant.

$$
\text { Yours faithfully, }
$$

$$
\text { R. C. LEWONTIN }
$$

University of Chicago

\section{Fulfilling Fulton}

SIR,-I was struck by the headline "Fulton Fulfilled" in your issue of October 8 (Nature, 233, 365; 1971). I have only now seen it on my return from holiday, and I wondered what exciting civil service developments I had missed.

The introduction of an interim Science Category, satisfactory in structure terms but with pay arrangements that, despite our success in improving on the arbitration award, are still wholly unsatisfactory, is a long way indeed from the fulfilment of Fulton.

There is the question of pay. The Institution did not accept that pay research was valid for scientists, and we refuse now to believe that they can reasonably be paid less than technologists or administrators. We are determined that we shall not again have pay research applied in an area where it is so clearly inapplicable. We shall redouble our efforts over the coming months to find a relevant basis for the pay of scientists. Then there is the question of careers; as I believe, the most important issue of all. On that, we are currently engaged in discussions with the Civil Service Department, and I am optimistic that we shall make real progress by the spring of next year.

Yours faithfully,

Cyril CoOper

Deputy General Secretary

The Institution of Professional

Civil Servants,

Northumberland Street,

London WC2N $5 B S$

\section{Population and Economics}

SIR,-I suppose that your highly irresponsible editorial of November 5 (Nature, 234, 2; 1971) under the heading "Alice Economics" need not be considered seriously, but there is a danger that what you have written will be read by "young people and other innocents", to use your own phrase in the other context. Professor Scorer, whose views you criticize, is not the only one to draw attention to the ecological predicament which will be speeded up by an expansion of EEC, and it is a pity that you can do no more than poke fun of him; indeed the fact that you do this indicates your own uneasiness.

You suggest that Professor Scorer's premises are false by taking a series of examples. Thus you ask if it is an accident that the richest nation on Earth is the one most concerned about pollution. $\mathrm{No}$, it is not an accident, but must we industrialize and pollute every nation in the world before we become interested in the problems we are creating? You also ask if there is anything but economic growth that will free India of cholera. To free India of cholera would simply add a few more to the 14 or so million people that India is adding to the world every year. Economic growth cannot possibly help India and similar countries: if everyone in the world enjoyed the same standard of living and consumption as the average Londoner, the world's resources would disappear almost instantaneously. Indeed economic growth in the EEC and other industrial groupings will do nothing for India and the many other desperate nations except to encourage them to sell their dwindling raw materials even more rapidly to the expanding industrial complexes which so many see as a solution to all economic difficulties. Professor Scorer may be wrong as to why the resources of the sea are not as rich as they used to be. You think that over-fishing is the problem, he suggests pollution. You may both be right, but the common denominator is expanding human numbers and, especially in Europe, expanding human needs.

To argue that entering the EEC is anything more than a conspiracy to create opportunities for big business is misleading. The expanded economic unit will demand more and more resources from the under-developed world, whose populations are likely to continue to increase at a phenomenal rate, thanks to the "aid" we offer as a small token of our appreciation for their help. You may think this a joke, but have you considered that, taking into consideration the resources it will consume, every child born in England, Sweden or America is forty or fifty times the ecological disaster of one born in Ghana, Sierra Leone or Liberia?

Yours faithfully,

D. F. OWEN

Department of Animal Ecology,

University of Lund,

Ecology Building,

S-22362 Lund, Sweden

\section{Tax on Pollution}

SIR,-The recently reported claim of the salvage industries to be given zero rating for value-added tax may not only attract wide support but can also be extended. The operation of VAT will automatically provide the machinery for a pollutionadded tax, PAT, either as part of VAT or alongside it. By this means, the visible cost of each manufacturing process can gradually be made to include the social cost of the stress it imposes on the environment, and the price of a product can be made to cover the cost of its salvage, re-cycling or disposal.

Restrictive legislation, although a necessary adjunct, is widely recognized to be insufficient of itself to control environmental deterioration; it is too blunt an instrument, the enforcement of which is necessarily ponderous, expensive and therefore sporadic. PAT by contrast can provide effective economic pressures operating in detail day by day. Its application can be flexible, selective and finely graduated. Since rating for PAT would be subject to appeal based on expert testimony, it provides economic motivation for research aimed at elucidating the real effects of pollution and ecological disturbance. This knowledge is an essential prerequisite of right action in the preservation of our living environment.

Yours faithfully, Peter Fellgett

Department of Applied Physical Sciences, University of Reading,

Building 3, Earley Gate,

Whiteknights,

Reading RG6 $2 A L$ 